Diabetologia (1995) 38: 201-210

\title{
Weakened cellular scavenging activity against oxidative stress in diabetes mellitus: regulation of glutathione synthesis and efflux
}

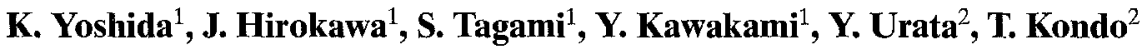 \\ ${ }^{1}$ First department of Medicine, Hokkaido University School of Medicine, Sapporo, Japan \\ ${ }^{2}$ Department of Pathological Biochemistry, Atomic Disease Institute, Nagasaki University School of Medicine, Nagasaki, Japan
}

Summary Glutathione functions to scavenge oxidants or xenobiotics by covalently binding them and transporting the resulting metabolites through an adenosine 5 '-triphosphate-dependent transport system. It has been reported that the intracellular concentration of glutathione decreases in diabetes mellitus. In order to elucidate the physiological significance and the regulation of anti-oxidants in diabetic patients, changes in the activity of the glutathionesynthesizing enzyme, $\gamma$-glutamylcysteine synthetase, and transport of thiol [S-(2,4-dinitrophenyl)glutathione] were studied in erythrocytes from patients with non-insulin-dependent diabetes and K562 cells cultured with $27 \mathrm{mmol} / 1$ glucose for 7 days. The activity of $\gamma$-glutamylcysteine synthetase, the concentration of glutathione, and the thiol transport were $77 \%, 77 \%$ and $69 \%$, respectively in erythrocytes from diabetic patients compared to normal control subjects. Treatment of patients with an antidiabetic agent for 6 months resulted in the restoration of $\gamma$ glutamylcysteine synthetase activity, the concentra- tion of glutathione, and the thiol transport. A similar impairment of glutathione metabolism was observed in K562 cells with high glucose levels. The cytotoxicity by a xenobiotic (1-chloro-2,4-dinitrobenzene) was higher in K562 cells with high glucose than in control subjects $(50 \%$ of inhibitory concentration. $300 \pm 24 \mu \mathrm{mol} / 1$ vs $840 \pm 29 \mu \mathrm{mol} / 1, p<0.01$ ). Expression of $\gamma$-glutamylcysteine synthetase protein was augmented in K562 cells with high glucose, while enzymatic activity and expression of mRNA were lower than those in the control subjects. These results suggest that inactivation of glutathione synthesis and thiol transport in diabetic patients increases the sensitivity of the cells to oxidative stresses, and these changes may lead to the development of some complications in diabetes mellitus. [Diabetologia (1995) 38: 201-210]

Key words Glutathione, $\gamma$-glutamylcysteine synthetase, thiol transport, erythrocytes, cytotoxicity, noninsulin-dependent diabetes mellitus, K562 cells.
Received: 23 February 1994 and in revised form: 27 July 1994

Corresponding author: Dr. T. Kondo, Department of Pathological Biochemistry, Atomic Disease Institute, Nagasaki University School of Medicine, Nagasaki 852, Japan

Abbreviations: ATP, Adenosine 5'-triphosphate; NIDDM, non-insulin-dependent diabetes mellitus; GSH, $\gamma$-glutamylcysteinyl glycine; GSSG, glutathione disulphide; $\gamma$-GCS, $\gamma$-glutamylcysteine synthetase; mRNA, messenger ribonucleic acid; DNA, deoxyribonucleic acid; $\mathrm{C}_{50}, 50 \%$ inhibitory concentration; CDNB, 1-chloro-2,4-dinitrobenzene; GS-DNP, S-(2,4dinitrophenyl)glutathione; PSL, photostimulated luminescence.
In recent studies on the pathogenesis of diabetic complications, it has been proposed that cellular injury caused by intracellular alterations in the metabolism of defence systems against oxidative stress results in diabetic complications $[1,2]$.

It is known that there are defence systems against oxidative stresses inside the cells. Glutathione $(\gamma$-glutamylcysteinyl glycine, GSH) is present in most mammalian cells and plays an important role in many biological processes such as sulphur-containing amino acid metabolism, has functions in the synthesis of proteins and nucleic acids, and participates in the cellular defence system against oxidative stress by reducing disulphide linkage of proteins and other cel- 
lular molecules, or by scavenging free radicals and reactive oxygen intermediates [3]. GSH is synthesized intracellularly by two GSH synthesizing enzymes, $\gamma$-glutamylcysteine synthetase $(\gamma$-GCS) and glutathione synthetase. $\gamma$-GCS is the key enzyme for GSH synthesis [4]. This enzyme has been purified from rat kidneys, and its cDNA structure has been clarified [5]. GSH synthesis is believed to be an important factor in cellular defence when cells are exposed to oxidative stress by radiation or drugs. Recently, Goldwin et al. [6] reported that the levels of $\gamma$-GCS increase in drug-resistant malignancies in accordance with the levels of GSH, indicating the importance of GSH synthesis for cells to acquire drug resistance. Human erythrocytes contain a high concentration of $\mathrm{GSH}(2 \mathrm{mmol} / \mathrm{l})$ and its related enzymes such as glutathione peroxidase, glutathione reductase, glutathione S-transferase, $\gamma$-GCS and glutathione synthetase, which protection against oxidative damage in human erythrocyte membranes [7].

A previous report from our laboratory has indicated that a decrease in the concentration of GSH and an increase in the concentration of glutathione disulphide (GSSG) are observed in erythrocytes from patients with diabetes mellitus [8]. These changes resulting in an oxidant/anti-oxidant imbalance in diabetic patients were suggested to be the cause of cellular damage. Furthermore, a similar decrease in antioxidant activities was observed in aortic endothelial cells from diabetic experimental animals [9].

When cells are exposed to an electrophile, a kind of oxidant species, GSH forms a thiol compound with the electrophile by the catalytic reaction of glutathione S-transferase. Since the GSH S-conjugate formed has mutagenic and carcinogenic activities, further detoxification is required [10]. It is known that the cells transport thiols in a form of GSSG or GSH S-conjugates outward through adenosine $5^{\prime}$-triphosphate (ATP)-dependent efflux processes [1115]. The transport of GSH S-conjugate in erythrocytes was first reported by Board [11], and it was shown that the addition of 1-chloro-2, 4-dinitrobenzene (CDNB) to erythrocytes results in the efflux of S-(2,4-dinitrophenyl) glutathione (GS-DNP), and that the transport of this conjugate is inhibited by the depletion of intracellular ATP. We previously found the presence of two independent transport systems for GSSG [16] and also evidence that erythrocytes transport GSH S-conjugate through one of the transport systems for GSSG [12]. The presence of GSH S-conjugate-stimulated $\mathrm{Mg}^{2+}$-ATPase has been shown and partial characterization of this enzyme has been reported [17]. Recently, we found that the expression of $\gamma$-GCS and GSH S-conjugatestimulated $\mathrm{Mg}^{2+}$-ATPase is responsive to oxidative stress [18].

However, the pathological significance of impaired GSH metabolism in diabetic patients has not
Table 1. Clinical characteristics of the subjects

\begin{tabular}{lcc}
\hline & $\begin{array}{c}\text { NIDDM patients } \\
(n=15)\end{array}$ & $\begin{array}{c}\text { Control subjects } \\
(n=15)\end{array}$ \\
\hline Sex (male/female) & $9 / 6$ & $9 / 6$ \\
Age (years) & $57.7 \pm 9.2$ & $53.9 \pm 5.2$ \\
Weight (kg) & $59 \pm 6$ & $58 \pm 7$ \\
$\begin{array}{l}\text { Body mass index } \\
\left.\text { (kg per m }{ }^{2}\right)\end{array}$ & $23.43 \pm 2.58$ & $22.81 \pm 2.22$ \\
$\begin{array}{l}\text { Fasting plasma glucose } \\
\text { (mmol/1 plasma) }\end{array}$ & $13.28 \pm 2.00^{\mathrm{a}}$ & $5.45 \pm 0.22$ \\
$\begin{array}{l}\text { Glycated haemoglobin } \\
\left(\mathrm{HbA}_{1 \mathrm{c}}, \%\right)\end{array}$ & $10.6 \pm 1.3^{\mathrm{a}}$ & $5.3 \pm 0.2$ \\
\hline
\end{tabular}

Values are expressed as mean $\pm \mathrm{SD}$.

${ }^{\mathrm{a}} P<0.01$ vs control subjects

been fully understood. In the present study we investigated the intracellular defence system against oxidative stress using erythrocytes and K562 cells as materials, and attempted to elucidate the pathological importance of GSH synthesis and the active thioltransport in diabetes. K562 cells were established from acute erythroleukemia cells and are known to possess characteristics for erythroid cells [19], and some characteristics of GSH metabolism in these cells have been clarified [18].

\section{Subjects, materials and methods}

Materials. Glutathione reductase and DE-52 were purchased from Pharmacia Fine Chemicals (Uppsala, Sweden). Dowex-1 was from Bio-Rad Laboratories (Richmond, Calif., USA). $\alpha$ Cellulose, microcrystalline cellulose, and other chemicals and reagents were from Sigma (St. Louis, Mo., USA). $\left[{ }^{3} \mathrm{H}\right]$ Glycine was from New England Nuclear (Boston, Mass., USA). RPMI 1640 and fetal calf serum were from GIBCO (Grand Island, N.Y., USA). FITC-conjugated anti-rabbit IgG-mouse IgG was from Rockland (Gilbersville, Penn., USA). K562 cells were donated by the Japan Cancer Research Resources Bank (Tokyo, Japan).

Subjects. Erythrocytes from 15 patients with NIDDM [ 9 male, 6 female; $57.7 \pm 9.2$ years of age (mean \pm SD)] were used as subjects after informed consent was obtained from each patient. The clinical characteristics are shown in Table 1. Their fasting plasma glucose levels ranged from 9.55 to $16.98 \mathrm{mmol} /$ 1 , with a mean $\pm \mathrm{SD}$ value of $13.28 \pm 2.00 \mathrm{mmol} / \mathrm{l}$. The levels of $\mathrm{HbA}_{1 \mathrm{c}}$ were $10.6 \pm 1.3 \%$. Mean duration of NIDDM was $12 \pm 2$ years. Eight of the patients had been treated with an oral antidiabetic agent (acetohexamide), three with insulin, and four had received no medication. Patients taking either GSH, vitamin $\mathrm{C}$, or vitamin $\mathrm{E}$ were excluded. Fifteen healthy volunteers [nine male, six female; $53.9 \pm 5.2$ years of age (mean $\pm \mathrm{SD})]$ were used as control subjects.

Preparation of samples. Fresh venous blood collected in $1 \mathrm{mg}$ of EDTA $/ \mathrm{ml}$ following a $12-\mathrm{h}$ fast was rapidly freed of leucocytes and platelets by passing it through a small cellulose column at $4^{\circ} \mathrm{C}[20]$. The erythrocytes were washed three times with phosphate-buffered saline, $\mathrm{pH} 7.4$ at $4^{\circ} \mathrm{C}$. The erythro- 
cytes were frozen at $-20^{\circ} \mathrm{C}$ and then thawed at $37^{\circ} \mathrm{C}$ to effect haemolysis. The cellular debris was removed by centrifugation at $4{ }^{\circ} \mathrm{C}$ for $60 \mathrm{~min}$ at $5,000 \times \mathrm{g}$. The cytosolic fraction was employed for the estimation of enzyme activities. For the estimation of GSH or ATP, $2 \mathrm{ml}$ of whole blood was rapidly mixed with $1 \mathrm{ml}$ of ice-cold $20 \%$ trichloracetic acid or perchloric acid, respectively. These acid extracts were used in $6 \mathrm{~h}$.

K562 cells were maintained in RPMI 1640 medium supplemented with $10 \%$ fetal calf serum at $37^{\circ} \mathrm{C}$ in $5 \% \mathrm{CO}_{2}$ with $100 \%$ humidity. The cells were harvested by centrifugation at $4^{\circ} \mathrm{C}$. The cytosolic fraction of K562 cells was recovered by lysis via the addition of four volumes of $10 \mathrm{mmoll} \mathrm{NaH}_{2} \mathrm{PO}_{4} /$ $\mathrm{Na}_{2} \mathrm{HPO}_{4}$, pH 7.4, containing $0.5 \mathrm{mmol} / 1$ ethylenediamine tetraacetic acid, $0.1 \mathrm{mmol} / \mathrm{l} 2$-mercaptoethanol, and $0.5 \mathrm{mmol} / \mathrm{l}$ phenylmethylsulphonyl fluoride followed by sonication for 2 min. Preparation of the cytosolic fraction was done as described above.

Thiol transport. The activity of thiol transport was studied in erythrocytes by estimating GS-DNP efflux which was formed intracellularly. Unless otherwise indicated, erythrocytes were incubated for $4 \mathrm{~h}$ at $37^{\circ} \mathrm{C}$ at $20 \%$ haematocrit in $1 \%$ bovine serum albumin, $8 \mathrm{mmol} / 1$ glucose, $62 \mathrm{mmol} / 1 \mathrm{NaCl}, 40 \mathrm{mmol} / \mathrm{l}$ $\mathrm{NaH}_{2} \mathrm{PO}_{4} / \mathrm{Na}_{2} \mathrm{HPO}_{4}, 35 \mathrm{mmol} / \mathrm{l}$ Na-TES [N-Tris-(hydroxymenthy-2-aminomethane sulphonic acid)], pH 7.4 (buffer A), containing $45 \mu \mathrm{Ci}$ of $\left[{ }^{3} \mathrm{H}\right]$ glycine $(25 \mu \mathrm{Ci} / \mathrm{nmol})$. After the incubation, the cells were washed twice in 20 volumes of 0.15 $\mathrm{mol} / 1 \mathrm{NaCl}$, allowed to stand for $3 \mathrm{~min}$ at $37^{\circ} \mathrm{C}$ in the saline, and washed twice more to remove most of the residual $\left[{ }^{3} \mathrm{H}\right]$ glycine as described previously [21]. The transport experiment for GS-DNP was performed essentially according to the method of Lunn et al. [22] for the transport of GSSG, with a slight modification [21]. Briefly, erythrocytes containing labelled GSH were incubated in buffer $\mathrm{A}$, containing $0.5 \mathrm{mmol} / \mathrm{l}$ CDNB for $1 \mathrm{~h}$ at $37^{\circ} \mathrm{C}$. The cells were then washed with saline twice to remove residual CDNB and further incubated for $1 \mathrm{~h}$ at $37^{\circ} \mathrm{C}$. After incubation, aliquots of the supernatant fraction of the incubation mixture were diluted with 10 volumes of $0.5 \mathrm{mmol} / \mathrm{l}$ GS-DNP, $0.5 \mathrm{mmol} / 1$ glycine, $\mathrm{pH} 7.0$, and applied to a $10 \times 95-\mathrm{mm}$ column of Dowex- 1 (formate). The cell suspension was treated with an excess of t-butylhydroperoxide at $37^{\circ} \mathrm{C}$ for $20 \mathrm{~min}$. The same volume of $10 \%$ trichloracetic acid was added to the cell suspension. Trichloracetic acid in the supernatant was removed by mixing with diethyl ether, and the supernatant was applied to a Dowex-1 column (formate form). The column was eluted with a 50-ml linear gradient of 0 to $4 \mathrm{~mol} / \mathrm{l}$ formic acid. Each $2 \mathrm{ml}$ of fraction was collected and the radioactivity estimated. The peak fraction of radioactivity eluted approximately at $2 \mathrm{~mol} / \mathrm{l}$ formic acid was identical to that of carrier GS-DNP. The specific activity of GS-DNP was determined as that of $\left[{ }^{3} \mathrm{H}\right] \mathrm{GSH}$ as described previously [21]. Briefly, labelled GSH in the cell suspension was oxidized to GSSG with an excess of $\mathrm{t}$-butylhydroperoxide at $37^{\circ} \mathrm{C}$ for $20 \mathrm{~min}$. The same volume of $10 \%$ trichloracetic acid was added to the cell suspension. Trichloracetic acid in the supernatant was removed by mixing with diethyl ether, and the GSSG fraction in the supernatant was prepared using a Dowex- 1 column (formate form). The radioactivity of the fraction was estimated, and the concentration of GSSG in the peak fraction was assayed using an enzyme-recycling method as described previously [12]. The activity of GS-DNP transport was corrected for haemolysis and expressed as nmol GS-DNP · ml erythrocytes $^{-1} \cdot$ hour $^{-1}$.

Thiol transport of inside-out vesicles. The GS-DNP transport was examined using sealed inside-out vesicles from erythrocytes. Erythrocytes were separated into young and old erythro- cyte fractions on the basis of specific gravity using Percoll-Hypaque centrifugation [23]. Vesiculation and preparation of inside-out vesicles were performed as described previously [24]. The transport experiment was performed as previously described [12], using $25 \mu \mathrm{l}$ of vesicles, in $125 \mu \mathrm{l}$ of $10 \mathrm{mmol} / \mathrm{l}$ Tris$\mathrm{HCl}$, pH 7.4, containing $2 \mathrm{mmol} / 1 \mathrm{ATP}, 10 \mathrm{mmol} / 1 \mathrm{MgCl}_{2}$ and $0.5 \mathrm{mmol} / \mathrm{L}\left[{ }^{3} \mathrm{H}\right] \mathrm{GS}-\mathrm{DNP}$. The incubation at $37^{\circ} \mathrm{C}$ was terminated at $5 \mathrm{~min}$, and the transport rate was expressed as pmol GSDNP per $\mathrm{ml}$ inside-out vesicles per min. Vesicles without ATP served as blanks. GS-DNP was prepared enzymatically using glutathione S-transferase as described by Wahllander and Sies [25]. $\left[{ }^{3} \mathrm{H}\right]$ GS-DNP was prepared using $\left[{ }^{3} \mathrm{H}\right] \mathrm{GSH}$ and CDNB according to the same method used for unlabelled compounds.

Thiol transport of $K 562$ cells. The activity of thiol transport was studied in K562 cells by estimating GS-DNP efflux as described previously [18] using $5 \times 10^{6}$ of $\mathrm{K} 562$ cells and $45 \mu \mathrm{Ci}$ of $\left[{ }^{3} \mathrm{H}\right]$ glycine $(25 \mu \mathrm{Ci} / \mathrm{nmol})$. Before the transport experiment, cells containing labelled GSH were incubated with $25 \mu \mathrm{mol} / \mathrm{l}$ $\mathrm{CDNB}$ at $37^{\circ} \mathrm{C}$ for $2 \mathrm{~h}$. After the incubation, the cells were washed three times in 20 volumes of the incubation medium to remove excess CDNB as described previously [21]. The transport experiment in $\mathrm{K} 562$ cells was $15 \mathrm{~min}$ at $37^{\circ} \mathrm{C}$, and the transport activity in $\mathrm{K} 562$ cells was expressed as pmol $\cdot 10^{6}$ cells ${ }^{-1} \cdot \mathrm{min}^{-1}$.

Enzyme assay. The activity of $\gamma$-GCS was estimated using $L-\alpha-$ aminobutyrate, L-glutamic acid, and $\left[{ }^{32} \mathrm{P}\right]$-ATP as substrates as previously described [26]. The activity of glutathione Stransferase was estimated photometrically as described by Beutler [27]. One unit of enzyme activity was expressed as $1 \mu \mathrm{mol}$ substrate changed per min.

Estimation of $A T P$ and glutathione. Concentrations of intracellular ATP and GSH were estimated enzymatically as described by Beutler [27].

Immunological estimation. Immunological staining of the cells was performed as described by Kaplow [28]. $\gamma$-GCS was purified from human erythrocytes according to the method of Yan and Meister [5] using the enzyme from rat kidney. Rabbits were immunized with the enzyme and the rabbit anti-human $\gamma$-GCS obtained was used as the first antibody [18]. Mouse FITC-conjugated anti-rabbit immunoglobin antibody was used as the second antibody. A FACScan (Becton Dickinson, Oxford, UK) was used for the flow-cytometric analysis. The excitation wavelength was $488 \mathrm{~nm}$ by argon-ion laser, and green fluorescence from FITC collected through a $530 \mathrm{~nm}$ bandpass filter was measured on a log scale. The antigen content was expressed as fluorescence indices (the ratio between the mean fluorescence channel number of the cells in the presence of antibody and the presence of antibody and the presence of rabbit IgG as a blank).

Northern blot analysis. The cloned cDNA was isolated according to the method described by Goldwin et al. [6]. A human liver $\gamma$-GCS probe (267 bp corresponding to nucleotides 54320 of rat kidney $\gamma$-GCS) was generated from human liver mRNA by polymerase chain reaction [18]. This probe radiolabelled with ${ }^{32} \mathrm{P}$ using a random primer technique was used to screen a human fetal liver cDNA library in $\lambda \mathrm{gt11}$. Isolation of cytoplasmic RNA and Northern blot analysis were essentially based upon the method of Sambrook et al. [29]. Cytoplasmic RNAs isolated from K562 cells were subjected to electrophoresis in $1 \%$ agarose gels containing $0.6 \mathrm{~mol} / \mathrm{l}$ formaldehyde, subsequently transferred to nylon-membrane filters, and later 
K. Yoshida et al: Glutathione synthesis and efflux in diabetes

Table 2. Activities of $\gamma$-glutamylcysteine synthetase and thiol transport in erythrocytes

\begin{tabular}{|c|c|c|}
\hline & $\begin{array}{l}\text { NIDDM } \\
\text { patients } \\
(n=15)\end{array}$ & $\begin{array}{l}\text { Control } \\
\text { subjects } \\
(n=15)\end{array}$ \\
\hline $\mathrm{GSH}(\mathrm{mmol} / \mathrm{l})$ & $1.8 \pm 0.2^{b}$ & $2.2 \pm 0.3$ \\
\hline $\operatorname{ATP}(\mathrm{mmol} / 1)$ & $1.6 \pm 0.3$ & $1.7 \pm 0.2$ \\
\hline $\begin{array}{l}\gamma \text {-GCS } \\
\text { (units/ml erythrocytes) }\end{array}$ & $0.24 \pm 0.02^{\mathrm{b}}$ & $0.31 \pm 0.01$ \\
\hline $\begin{array}{l}\text { Glutathione } \\
\text { S-transferase } \\
\text { (units/ml erythrocytes) }\end{array}$ & $1.82 \pm 0.42$ & $1.79 \pm 0.36$ \\
\hline $\begin{array}{l}\text { Initial intracellular } \\
\text { GS-DNP formed } \\
\text { (nmol/ml erythrocytes) }\end{array}$ & $1152 \pm 62$ & $1166 \pm 77$ \\
\hline $\begin{array}{l}\text { GS-DNP transport rate } \\
\left(\text { amol } \cdot \text { ml erythrocytes }{ }^{-1} \cdot \mathrm{h}^{-1}\right)\end{array}$ & $297 \pm 31^{a}$ & $430 \pm 13$ \\
\hline
\end{tabular}

Values are expressed as mean $\pm \mathrm{SD}$.

${ }^{\mathrm{a}} p<0.01$ and ${ }^{\mathrm{b}} p<0.05$ vs control subjects

hybridized with $\left[{ }^{32} \mathrm{P}\right]$-labelled nick-translated probes for $\gamma$ GCS. Autographed filters were analysed using a Fujix BioAnalyzer BAS-2000 (Fuji Photo Film, Japan). The relative radioactivity was expressed as photostimulated luminescence (PSL) [30].

Cytotoxicity assay. CDNB sensitivity was determined by tetrazorium salt assay [31] based on the evidence that living cells are able to convert a tetrazorium salt to a blue formazan product. Cells $(5,000-10,000)$ were plated in $150 \mu \mathrm{l}$ of medium per well in a 96-well plate. Two hours after the addition of $0.1 \mathrm{mmol} / \mathrm{l} \mathrm{CDNB}$, the cells were incubated for $4 \mathrm{~h}$ at $37^{\circ} \mathrm{C}$ with 3-(4, 5-dimethylthiazol-2-yl)-2, 5-diphenyltetrazorium bromide $(5 \mathrm{mg} / \mathrm{ml})$. The cells were lysed with $100 \mu \mathrm{l}$ of $20 \%$ sodium dodecyl sulphate $/ 50 \% \mathrm{~N}, \mathrm{~N}$-dimethyl-formamide, $\mathrm{pH}$ 4.7, in each well. After incubation overnight, the absorbance at $570 \mathrm{~nm}$ was measured. The wells in the absence of cells served as blanks. Cytotoxicity was expressed as $50 \%$ of inhibitory concentration $\left(\mathrm{IC}_{50}\right)$.

\section{Statistical analysis}

The data are given as mean \pm SD. Differences were calculated with Student's $t$-test.

\section{Results}

Activity of $\gamma-G C S$ and thiol transport in erythrocytes from diabetic patients. As shown in Table 2, a decrease in the activity of $\gamma$-GCS was observed in erythrocytes from diabetic patients $(n=15)$ in comparison to those from normal control subjects $(n=15)$ (77\% of control subjects) $(0.24 \pm 0.02$ units per ml erythrocytes vs $0.31 \pm 0.01$ units per $\mathrm{ml}$ erythrocytes, $p<0.05)$. The concentration of intracellular GSH also decreased in the cells from diabetic patients ( $77 \%$ of control subjects) $(1.8 \pm 0.2 \mathrm{mmol} / \mathrm{l}$ vs $2.2 \pm 0.3 \mathrm{mmol} / 1, p<0.05$ ), while no apparent change was seen in the concentration of ATP or the activity of glutathione S-transferase in good agreement with the data reported previously [6]. Incubation of erythrocytes with $0.5 \mathrm{mmol} / \mathrm{l} \mathrm{CDNB}$ for $1 \mathrm{~h}$ at $37^{\circ} \mathrm{C}$ results in the formation of GS-DNP. The intracellular concentration of GS-DNP formed in erythrocytes from diabetic patients was not different from that of normal control subjects. A significant decrease in the GS-DNP transport was observed in diabetic patients in comparison to that in normal control subjects by $69 \% \quad\left(297 \pm 31 \mathrm{nmol} \cdot \mathrm{ml}\right.$ erythrocytes ${ }^{-1} \cdot \mathrm{h}^{-1}$ vs $430 \pm 13 \mathrm{nmol} \cdot \mathrm{ml}$ erythrocytes $\left.{ }^{-1} \cdot \mathrm{h}^{-1}, p<0.01\right)$. Effects of treatment with an antidiabetic agent, acetohexiamide, on the changes in the activity of GSDNP transport were estimated using four untreated diabetic patients (Table 3 ). These patients had not been treated previously, and treatment with acetohexamide was begun and continued during the observation period for 6 months. Improvement of the levels of $\mathrm{HbA}_{1 \mathrm{c}}$ from $11.1 \pm 1.2 \%$ to $6.7 \pm 0.9 \%$ and

Table 3. Changes in the antioxidant activities in erythrocytes during treatment with antidiabetic agents

\begin{tabular}{|c|c|c|c|c|c|}
\hline & $\begin{array}{l}\text { Treatment } \\
\text { (month) }\end{array}$ & $\begin{array}{l}\mathrm{HbA}_{1 \mathrm{c}} \\
(\%)\end{array}$ & $\begin{array}{l}\text { GS-DNP transport } \\
\left(\text { nmol } \cdot \text { ml erythrocytes }{ }^{-1} \cdot h^{-1}\right)\end{array}$ & $\begin{array}{l}\gamma \text {-GCS } \\
\left(\text { units } \cdot \text { ml erythrocytes }{ }^{-1} \text { ) }\right.\end{array}$ & $\begin{array}{l}\text { GSH } \\
(\mathrm{mmol} / 1)\end{array}$ \\
\hline Patient 1 & $\begin{array}{l}\text { before } \\
3 \\
6\end{array}$ & $\begin{array}{l}11.7 \\
9.0 \\
6.2\end{array}$ & $\begin{array}{l}257 \\
295 \\
385\end{array}$ & $\begin{array}{l}0.22 \\
0.27 \\
0.35\end{array}$ & $\begin{array}{l}1.5 \\
1.8 \\
2.2\end{array}$ \\
\hline Patient 2 & $\begin{array}{l}\text { before } \\
3 \\
6\end{array}$ & $\begin{array}{l}9.6 \\
7.4 \\
5.7\end{array}$ & $\begin{array}{l}349 \\
375 \\
407\end{array}$ & $\begin{array}{l}0.26 \\
0.33 \\
0.37\end{array}$ & $\begin{array}{l}1.8 \\
2.1 \\
2.3\end{array}$ \\
\hline Patient 4 & $\begin{array}{l}\text { before } \\
3 \\
6\end{array}$ & $\begin{array}{l}12.4 \\
9.5 \\
7.0\end{array}$ & $\begin{array}{l}258 \\
297 \\
352\end{array}$ & $\begin{array}{l}0.16 \\
0.25 \\
0.31\end{array}$ & $\begin{array}{l}1.4 \\
1.7 \\
1.9\end{array}$ \\
\hline
\end{tabular}

Effect of treatment with an oral antidiabetic agent, acetohexamide, on the changes in the activity of $\gamma$-GCS, the GS-DNP transport, and the concentration of GSH were estimated in four untreated diabetic patients 
an increase in the GS-DNP-transport from $287 \pm 42$ $\mathrm{nmol} \cdot \mathrm{ml}$ erythrocytes ${ }^{-1} \cdot \mathrm{h}^{-1}$ to $376 \pm 25 \mathrm{nmol} \cdot \mathrm{ml}$ erythrocytes $^{-1} \cdot \mathrm{h}^{-1}$ were observed in each case. There were also improvements in the activity of $\gamma$-GCS due to this treatment from $0.20 \pm 0.05$ units $\cdot \mathrm{ml}$ erythrocytes $^{-1}$ to $0.33 \pm 0.03$ units $\cdot \mathrm{ml}$ erythrocytes ${ }^{-1}$ in 6 months, and that of the concentration of GSH from $1.6 \pm 0.2 \mathrm{mmol} / 1$ to $2.1 \pm 0.2 \mathrm{mmol} / 1$. There was a negative correlation between the levels of HbA1c and the GS-DNP transport in the diabetic patients $(r=0.83, p<0.01)$ as shown in Fig. 1 .

Thiol transport of inside-out vesicles. The transport activity of GS-DNP was estimated simultaneously using erythrocytes and inside-out vesicles of erythrocytes (Table 4 ). The GS-DNP transport in the young fraction from diabetic patients $(n=4)$ was $79 \%$ of that from normal control subjects $(n=4)(370 \pm 13$ $\mathrm{nmol} \cdot \mathrm{ml}$ erythrocytes ${ }^{-1} \cdot \mathrm{h}^{-1}$ vs $468 \pm 38 \mathrm{nmol} \cdot \mathrm{ml}$ erythrocytes $\left.^{-1} \cdot \mathrm{h}^{-1}, p<0.01\right)$. The GS-DNP transport in the old erythrocyte fraction from diabetic patients was $63 \%$ of that from normal control subjects $\left(246 \pm 30 \mathrm{nmol} \cdot \mathrm{ml}\right.$ erythrocytes $^{-1}$ vs $388 \pm 42$ $\mathrm{nmol} \cdot \mathrm{ml}$ erythrocytes $\left.{ }^{-1} \cdot \mathrm{h}^{-1}, \quad p<0.01\right)$. The GSDNP transport of inside-out vesicles from diabetic patients was lower than that of normal control subjects $(n=4)$ both in the young erythrocyte fraction $\left(1635 \pm 45 \mathrm{pmol} \cdot \mathrm{ml}\right.$ vesicles ${ }^{-1} \cdot \mathrm{min}^{-1}$ vs $2195 \pm 97$ pmol $\cdot \mathrm{ml}$ vesicles $\left.{ }^{-1} \cdot \min ^{-1}, p<0.01\right)$, and in the old erythrocyte fraction $\left(793 \pm 12 \mathrm{pmol} \cdot \mathrm{ml}\right.$ vesicles $^{-1}$. $\mathrm{min}^{-1}$ vs $1321 \pm 80 \mathrm{pmol} \cdot \mathrm{ml}$ vesicles ${ }^{-1} \cdot \mathrm{min}^{-1}$, $p<0.01$ ).

Effect of glucose on the activity of $\gamma$-glutamylcysteine synthetase and thiol transport in K562 cells. K562 cells were incubated with various concentrations of D-glucose from $5.5 \mathrm{mmol} / \mathrm{l}$ to $27 \mathrm{mmol} / 1$ for 7 days and the effect of a high glucose concentration on the GSH metabolism was studied.

The concentration of GSH decreased depending on the concentration of glucose in the medium (Fig.2). The following experiments were performed using K562 cells cultured with $27 \mathrm{mmol} / 1$ glucose for 7 days, and the cells with $8 \mathrm{mmol} / 1$ glucose were used as normal controls. As shown in Table 5, the concentration of GSH in the presence of $27 \mathrm{mmol} / 1$ glucose was significantly lower than that in the control subjects $\left(0.8 \pm 0.1 \mathrm{nmol} \cdot 10^{6}\right.$ cells $^{-1}$ vs $1.4 \pm 0.1 \mathrm{nmol} \cdot 10^{6}$ cells $\left.^{-1}, \quad p<0.01\right)$. Incubation of the cells with $27 \mathrm{mmol} / 1$ glucose also resulted in a $40 \%$ decrease in the activity of $\gamma$-GCS over 7 days $\left(6.9 \pm 0.1 \mathrm{mU} \cdot 10^{6}\right.$ cells $^{-1}$ vs $11.5 \pm 1.8 \mathrm{mU} \cdot 10^{6}$ cells $\left.^{-1}, p<0.05\right)$. The GS-DNP transport also decreased in high-glucoseexposed K562 cells to $62 \%$ of that in the control subjects $\left(21.2 \pm 3.1 \mathrm{pmol} \cdot 10^{6} \mathrm{cells}^{-1} \cdot \mathrm{min}^{-1}\right.$ vs $35.9 \pm 5.4$ $\left.\mathrm{pmol} \cdot 10^{6} \mathrm{cells}^{-1} \cdot \mathrm{min}^{-1}, \quad p<0.01\right)$. There was no change either in the activity of glutathione S-transferase or in the levels of ATP.

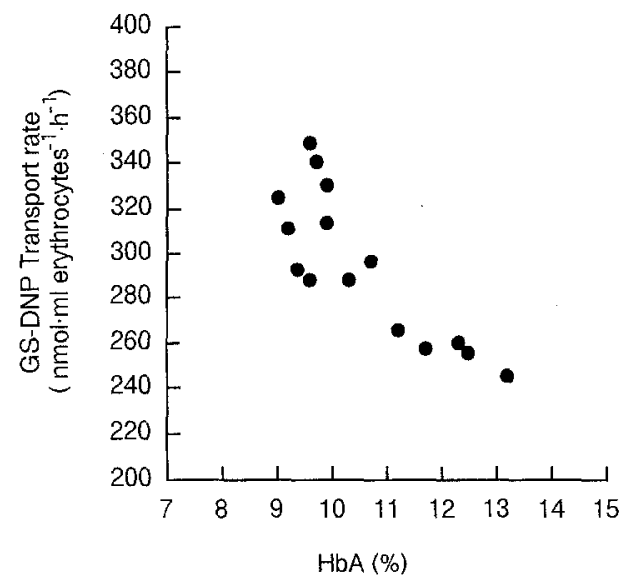

Fig. 1 Relationship between the levels of glycated haemoglobin and the activity of thiol transport. Correlation between the levels of $\mathrm{HbA}_{1 \mathrm{c}}(\%)$ and the transport of GS-DNP (nmol erythrocytes ${ }^{-1} \cdot \mathrm{h}^{-1}$ ) was estimated in erythrocytes from 15 diabetic patients

Table 4. Effect of cell age on the thiol transport in erythrocytes

\begin{tabular}{lll}
\hline & \multicolumn{2}{l}{ Transport of GS-DNP } \\
\cline { 2 - 3 } & $\begin{array}{l}\text { NIDDM patients } \\
(n=4)\end{array}$ & $\begin{array}{l}\text { Control subjects } \\
(n=4)\end{array}$ \\
\hline Erythrocytes & $\begin{array}{l}(\mathrm{nmol} \cdot \mathrm{ml} \\
\text { erythrocytes }\end{array}$ & \\
& $370 \pm 13^{\mathrm{a}}$ & \\
young fraction & $246 \pm 30^{\mathrm{a}}$ & $468 \pm 38$ \\
old fraction & $\mathrm{pmol} \cdot \mathrm{ml}^{-1}$ & $388 \pm 42$ \\
$\begin{array}{l}\text { Inside-out vesicles } \\
\text { from erythrocytes }\end{array}$ & vesicles $\left.\mathrm{mm}^{-1}\right)$ & \\
$\begin{array}{l}\text { young fraction } \\
\text { old fraction }\end{array}$ & $\begin{array}{c}1635 \pm 45^{\mathrm{a}} \\
793 \pm 12^{\mathrm{a}}\end{array}$ \\
\hline
\end{tabular}

Erythrocytes were separated into two groups by centrifugation on the basis of specific gravity and inside-out vesicles were prepared from these erythrocytes. Values are expressed as mean \pm SD. ${ }^{a} p<0.01$ vs control subjects

Immunological levels of $\gamma$-glutamylcysteine synthetase. Immunological levels of $\gamma$-GCS were estimated using a flow-cytometric method. In high-glucose-exposed K562 cells, the expression of $\gamma$-GCS increased on the 3rd day, and it was $190 \%$ of that of the normal control subjects on the 7th day (index 18.1 on the 7 th day vs 9.5 of control, typical data from triplicate analyses) (Fig. 3).

Northern blot analysis of $\gamma$-glutamylcysteine synthetase. Expression of $\gamma$-GCS mRNA was estimated in K562 cells. The cells were incubated with $27 \mathrm{mmol} / \mathrm{l}$ glucose and aliquots of the cells were drawn during the incubation. As shown in Figure 4, the stimulatory effect of the addition of $27 \mathrm{mmol} / 1$ glucose on the expression of $\gamma$-GCS mRNA was observed at $72 \mathrm{~h}$ of the incubation (a PSL value of 300 at $72 \mathrm{~h}$ vs 146 of the control subjects). The increase in the expression of $\gamma$-GCS mRNA declined to the basal level in 7 


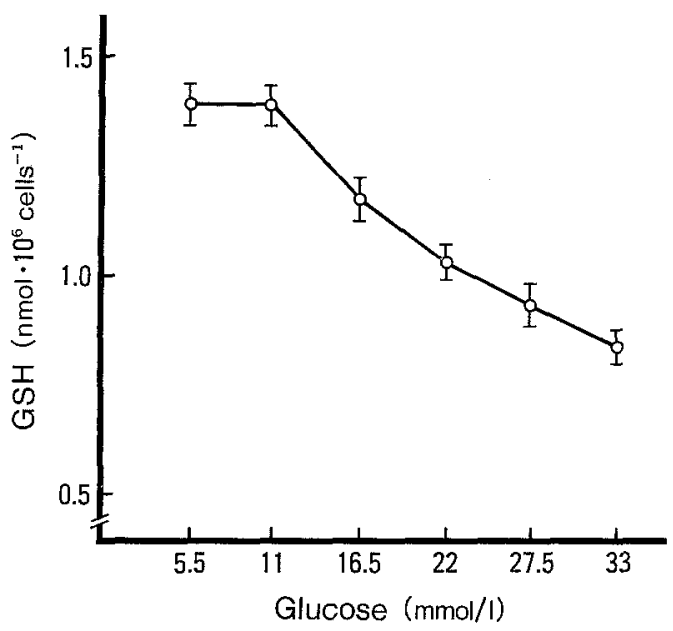

Fig. 2 Effect of glucose on the GSH concentration. K562 cells were incubated for 7 days with various glucose concentrations. The concentration of intracellular GSH was estimated. Mean $\pm \mathrm{SD}$ of four different analyses

days, while the activity of $\gamma$-GCS showed a gradual decrease during the incubation (Fig.5).

Cytotoxicity. Cytotoxic effects of CDNB on K562 cells were estimated (Table 6). K562 cells incubated with $27 \mathrm{mmol} / \mathrm{l}$ glucose for 7 days showed an increase in the sensitivity to $\mathrm{CDNB} \quad\left[\mathrm{IC}_{50}\right.$ $300 \pm 24 \mu \mathrm{mol} / 1$ vs $840 \pm 29 \mu \mathrm{mol} / 1, p<0.01$ (four different analyses)]. Previous incubation of the cells with $50 \mu \mathrm{mol} / \mathrm{l}$ buthionine sulfoximine for $48 \mathrm{~h}$ resulted in a $21 \%$ decrease in the concentration of intracellular GSH $\left(1.1 \pm 0.1 \mathrm{nmol} \cdot 10^{6}\right.$ cells $^{-1}$ vs $1.4 \pm 0.1$ $\mathrm{nmol} \cdot 10^{6}$ cells $\left.^{-1}, p<0.05\right)$ and a $35 \%$ decrease in the $\mathrm{IC}_{50}$ value $(546 \pm 20 \mu \mathrm{mol} / \mathrm{l}$ vs $840 \pm 29 \mu \mathrm{mol} / \mathrm{l}$, $p<0.01$ ). The addition of $1 \mathrm{mmol} / 1$ sodium fluoride, a inhibitor of the GS-DNP transport, resulted in a $20 \%$ decrease in the transport $\left(58.2 \pm 5.5 \mathrm{pmol} \cdot 10^{6}\right.$ cells ${ }^{-1} \cdot \mathrm{min}^{-1}$ vs $72.7 \pm 6.0 \mathrm{pmol} \cdot 10^{6} \mathrm{cells}^{-1} \cdot \mathrm{min}^{-1}$, $p<0.05$ ) and a $12 \%$ decrease in the $\mathrm{IC}_{50}$ value $(739 \pm 17 \mu \mathrm{mol} / \mathrm{l}$ vs $840 \pm 29 \mu \mathrm{mol} / \mathrm{l}, p<0.05)$. Treatment of the cells both with $50 \mu \mathrm{mol} / \mathrm{l}$ buthionine sulfoximine and $1 \mathrm{mmol} / \mathrm{l}$ sodium fluoride resulted in a further decrease of the $\mathrm{IC}_{50}$ value to $52 \%$
$\mathrm{K}$. Yoshida et al.: Glutathione synthesis and efflux in diabetes

$(399 \pm 15 \mu \mathrm{mol} / 1$ vs $840 \pm 29 \mu \mathrm{mol} / 1, p<0.01)$. Effect of a glycation inhibitor, aminoguanidine, was also studied. Treatment of the cells with $27 \mathrm{mmol} / \mathrm{l}$ glucose for 7 days in the presence of $1 \mathrm{mmol} / 1$ aminoguanidine resulted in restoration of the glutathione metabolism (the level of GSH; $1.3 \pm 0.1 \mathrm{nmol} \cdot 10^{6}$ cells $^{-1}$, GS-DNP transport rate; $67.8 \pm 6.0 \mathrm{pmol} \cdot 10^{6}$ cells ${ }^{-1} \cdot \mathrm{min}^{-1}$, respectively) as well as increase in the level of $\mathrm{IC}_{50}(760 \pm 30 \mu \mathrm{mol} / 1)$.

\section{Discussion}

Oxygen radicals and xenobiotics cause tissue damage. Impairment of cellular constituents by depletion of GSH using buthionine sulfoximine, a specific inhibitor of the GSH-synthesizing step, was reported by Meister [32] and Martensson et al. [33]. In diabetes, hyperglycaemia is thought to cause glycation and oxidation, and a decrease in the scavenging activity against oxidative stress. These changes may play a crucial role in the development of cell damage and diabetic complications. Injury to pancreatic beta cells by oxidant radicals is believed to bring about insulitis and cause insulin-dependent diabetes mellitus $[1,2]$. Recently, Oogawara et al. [34] have reported the glycation reaction of $\mathrm{Cu}, \mathrm{Zn}$-superoxide dismutase brings about fragmentation of this enzyme, in which mechanisms involving reactive oxygen species are thought to play a role.

Previously, we have shown evidence of the impairment of the anti-oxidant system in erythrocytes from diabetic patients [8] and in aortic endothelial cells from diabetic experimental animals [9]. However, the pathological significance of this impairment of GSH metabolism in diabetes has not been fully clarified.

In the present study, we employed human erythrocytes and K562 cells to investigate the regulation of the GSH metabolism in diabetes. The present study showed that the activity of $\gamma$-GCS decreased in erythrocytes from diabetic patients restored to the levels in normal control subjects when the patients were treated with an antidiabetic agent for 6 months,

Table 5. Glutathione metabolism and cytotoxicity in K562 cells

\begin{tabular}{lcr}
\hline & $\begin{array}{c}\text { High glucose exposed } \\
(27 \text { mmol/l glucose })\end{array}$ & $\begin{array}{c}\text { Control subjects } \\
(8 \mathrm{mmol} / \mathrm{l} \text { glucose })\end{array}$ \\
\hline GSH $\left(\mathrm{nmol} \cdot 10^{6} \mathrm{cells}^{-1}\right)(n=15)$ & $0.8 \pm 0.1^{\mathrm{a}}$ & $1.4 \pm 0.1$ \\
ATP $\left(\mathrm{nmol} \cdot 10^{6} \mathrm{cells}^{-1}\right)(n=15)$ & $1.2 \pm 0.1$ & $1.2 \pm 0.1$ \\
$\gamma$-GCS $\left(\mathrm{mU} \cdot 10^{6} \mathrm{cells}^{-1}\right)(n=15)$ & $6.9 \pm 0.1^{\mathrm{b}}$ & $11.5 \pm 1.8$ \\
Glutathione S-transferase $\left(\mathrm{mU} \cdot 10^{6} \mathrm{cells}-1\right)(n=15)$ & $12.6 \pm 4.0$ & $12.1 \pm 3.0$ \\
Intracellular GS-DNP formed $\left(\mathrm{nmol} \cdot 10^{6} \mathrm{cells}^{-1}\right)(n=4)$ & $0.58 \pm 0.01$ & $0.63 \pm 0.01$ \\
GS-DNP transport rate $\left(\mathrm{pmol} \cdot 10^{6} \mathrm{cells}^{-1} \cdot \mathrm{min}^{-1}\right)(n=4)$ & $22.2 \pm 3.1^{\mathrm{a}}$ & $35.9 \pm 5.4$ \\
IC & $300 \pm 24^{\mathrm{a}}(\mu \mathrm{mol} / \mathrm{l})(n=4)$ & $840 \pm 29$ \\
\hline
\end{tabular}

K562 cells incubated for 7 days in the presence of $27 \mathrm{mmol} / \mathrm{l}$ glucose served as high-glucose exposed cells, and those incubated in $8 \mathrm{mmol} / 1$ glucose as controls. Values are expressed as mean $\pm \mathrm{SD}$

${ }^{\mathrm{a}} p<0.01$ and ${ }^{\mathrm{b}} p<0.05$ vs control subjects 

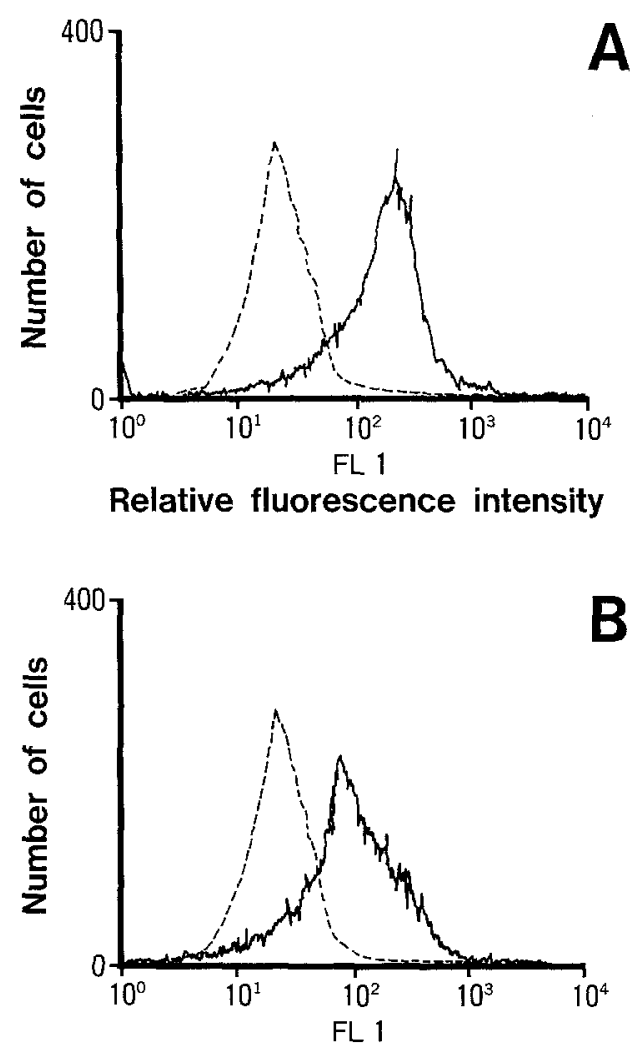

Relative fluorescence intensity

Fig.3 (A, B) Flow cytometric analysis of $\gamma$-GCS in K562 cells. Effect of the incubation of K562 cells with $27 \mathrm{mmol} / 1$ glucose on the immunological levels of $\gamma$-GCS were analysed using a flow cytometer. Expression of $\gamma$-GCS was estimated using anti- $\gamma$-GCS rabbit IgG as a first antibody and FITC-conjugated anti-rabbit IgG mouse serum as a second antibody. The levels are expressed as fluorescence indices. (A) $27 \mathrm{mmol} / 1 \mathrm{glu}-$ cose; (B) control. Shift of the peak of the relative fluorescence intensity (18.1) is observed on day $7(\mathbf{A})$, from that of control subjects (9.5) on the same day (B)

with a concomitant increase in the levels of GSH. The activity of GS-DNP transport also decreased in diabetic patients, and was normalized by treatment of the patients in accordance with a decrease in the levels of $\mathrm{HbA}_{1 \mathrm{c}}$. There was a negative correlation between the levels of $\mathrm{HbA}_{1 \mathrm{c}}$ and the GS-DNP transport, as well as the negative correlation between the $\mathrm{HbA}_{1 \mathrm{c}}$ and the concentration of GSH or the activity of $\gamma$-GCS (data not shown). A possible explanation for these changes may be glycation of $\gamma$-GCS as observed in other cytoplasmic enzymes in erythrocytes such as carbonic anhydrase [35] or $\mathrm{Cu}, \mathrm{Zn}$-superoxide dismutase [34].

Incubation of K562 cells with $27 \mathrm{mmol} / 1$ glucose for 7 days resulted in a change in the GSH metabolism similar to that observed in erythrocytes as described above. The cells exposed to a high glucose concentration were highly sensitive to CDNB. Sensitivity to CDNB was augmented by treatment of the cells with a inhibitor of $\gamma$-GCS, buthionine sulfoximine, or that of GS-DNP transport, sodium fluor-

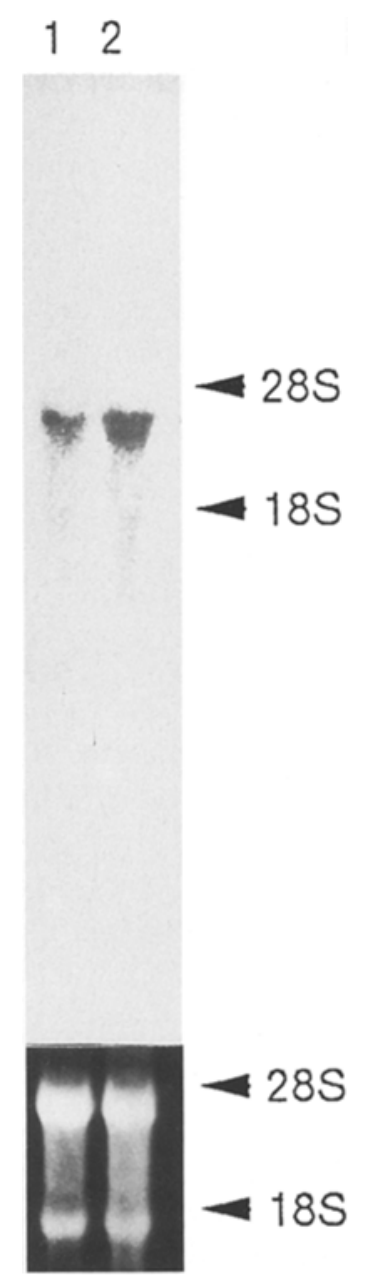

Fig. 4 Northern blot analysis of $\gamma$-GCS mRNA. Approximately $30 \mu \mathrm{g}$ of each total RNA extracted from K 562 cells was fractionated by electrophoresis, subsequently transferred to nylonmembrane filters, and later hybridized with $\mathrm{P}^{32}$-labelled nick translated $\gamma$-GCS DNA. Upper panel; (A) $27 \mathrm{mmol} / 1$ glucose; (B) control. Equivalent amounts of total RNA were analysed in each case and the positions of the $28 \mathrm{~S}$ and $18 \mathrm{~S}$ ribosome are indicated in the lower panel

ide. Simultaneous treatment of the cells with these inhibitors resulted in a further increase of the sensitivity to CDNB. These results suggest that both GSH synthesis and the GS-DNP transport play important roles in the defence system and that their impairment in hyperglycaemic cells causes an increase in the sensitivity to oxidative stress.

The importance of $\gamma$-GCS in cellular defence system is supported by the evidence that this mRNA is highly responsive to heat shock and chemical insults such as iodoacetamide, metals, and amino acid similar to the expression of heat shock protein [18]. Northern blot analysis in the present study showed an apparent increase in the expression of $\gamma$-GCS mRNA in the 72 nd $h$ when K562 cells were incubated with high-glucose, corresponding to the decrease in the activity of $\gamma$-GCS; this increase in the levels of mRNA was followed by an increase in the immunolo- 


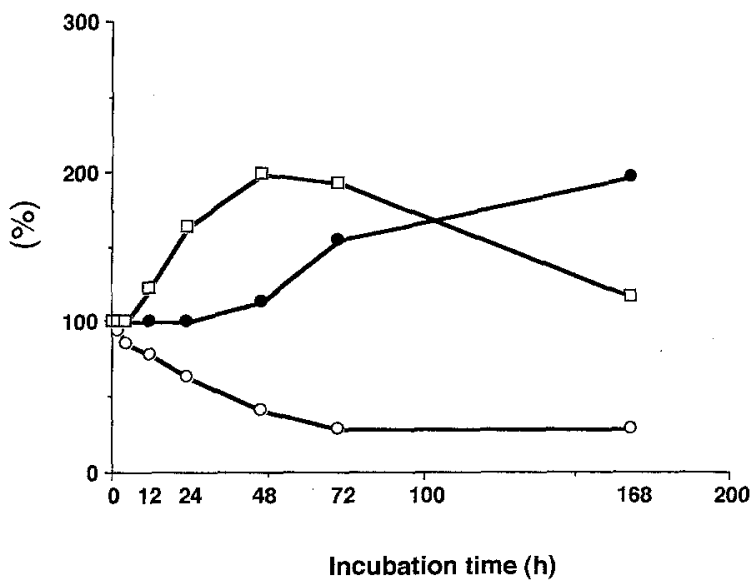

Fig. 5 Changes in $\gamma$-GCS during incubation of K562 cells with glucose. K562 cells were incubated with $27 \mathrm{mmol} / \mathrm{l}$ glucose and aliquots were drawn for the estimation of the activity (O), immunological level (O), and mRNA of $\gamma$-GCS( $\square$ ). The values were expressed as a percent of the initial values, respectively

gical levels of $\gamma$-GCS. However, the activity of $\gamma$-GCS showed a gradual decrease during the incubation of the cells with $27 \mathrm{mmol} / 1$ glucose. On day 7 of the incubation, the expression of $\gamma$-GCS mRNA, the level of $\gamma$-GCS protein and the activity of $\gamma$-GCS were approximately $100 \%, 190 \%$ and $45 \%$ of those on day 0 , respectively. Decrease in the activity of $\gamma$-GCS with a higher level of this enzyme protein in the cells cultured under high glucose conditions indicates that $\gamma$-GCS is inactivated in diabetic conditions, although the mechanisms are not known. The expression of $\gamma$ GCS mRNA was not responsive to the decrease in the intracellular GSH in diabetic conditions. The precise mechanism by which the expression of $\gamma$-GCS mRNA is regulated is not clear; however, it is suggested that the impairment of the expression of $\gamma$-GCS mRNA contributes to the decrease in $\gamma$-GCS activity and GSH.
K. Yoshida et al.: Glutathione synthesis and efflux in diabetes

The mechanisms by which thiol transport is impaired in erythrocytes from diabetic patients and K562 cells exposed to high glucose are also unknown. There may be possible reasons for the decrease in GSH metabolism such as a decrease in the levels of ATP or GSH, or the activity of glutathione S-transferase. The intracellular concentrations of ATP, the activity of glutathione S-transferase and GS-DNP formed in diabetic patients were the same as those in normal control subjects. The activity of GS-DNP transport using inside-out vesicles from erythrocytes of diabetic patients was lower than that of normal control subjects both in the young and old erythrocyte fractions. In this experiment, the same concentration of GS-DNP was used, and other factors such as the concentrations of ATP and $\mathrm{Mg}^{2+}$ were the same.

Alteration of membrane structure and fluidity has been established in diabetic subjects $[36,37]$. It is not known if autophosphorylation is involved in activation for $\gamma$-GCS activity or the thiol transport. Impairment of phosphorylation for some proteins on cytoplasmic membranes such as the insulin receptor or the glucose transporter have been reported in diabetic subjects [38]. Differences in the phosphorylation of proteins may be another explanation for the decrease in thiol transport.

Aminoguanidine, a nucleophilic hydrazine compound, is known to prevent the formation of glycation products and glucose-derived collagen crosslinks, and inhibit aldose reductase and diamine oxidase, though the primary mechanism of these reactions is not fully understood $[39,40]$. In the present study, neither the level of GSH nor the activity of thiol transport were impaired when K562 cells were incubated with $27 \mathrm{mmol} / \mathrm{l}$ glucose in the presence of aminoguanidine. These data suggest that glucose-derived modification of $\gamma$-GCS and the thiol transport system is one of the factors for the decrease in their

Table 6. Effect of inhibitors for glutathione metabolism on the cytotoxicity in K562 cells

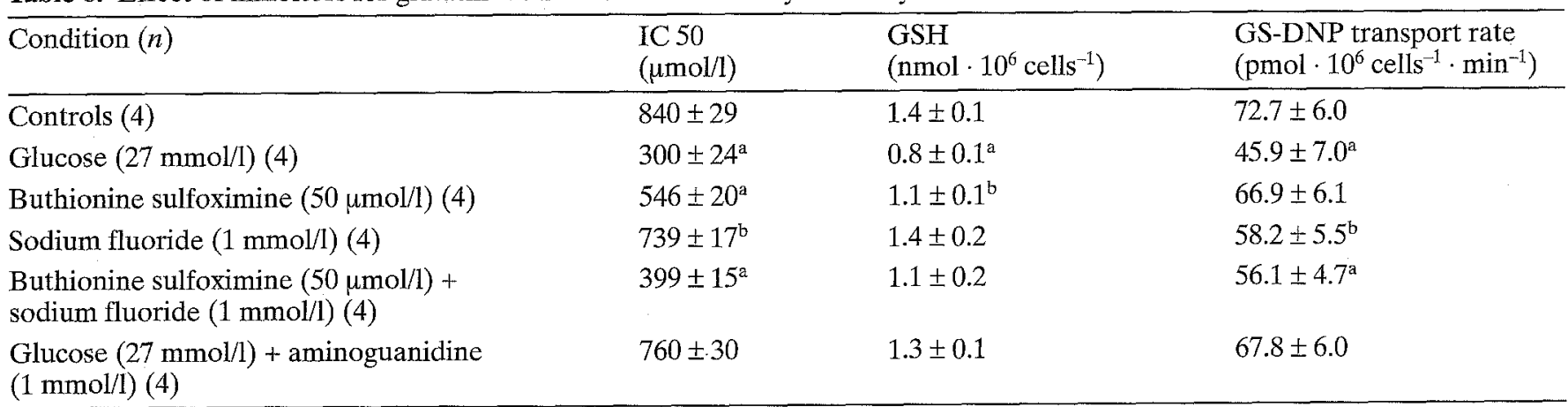

K562 cells were incubated for 7 days in the presence of $27 \mathrm{mmol} / \mathrm{l}$ glucose or $8 \mathrm{mmol} / \mathrm{l}$ glucose. Cytotoxicity was determined by assay with 3-(4,5-dimethylthiazol-2-yl) 2,5-diphenyltetrazorium bromide. The IC 50 is the concentration of CDNB (umol/l) that inhibited growth by $50 \%$. Cells in the absence of CDNB served as blanks. Buthionine sulfoximine was added $48 \mathrm{~h}$ before and sodium fluoride just before the cytotoxicity assay. Aminoguanidine was added and cultured in the presence of $27 \mathrm{mmol} / \mathrm{l}$ glucose for 7 days.

Values are expressed as mean \pm SD.

${ }^{\mathrm{a}} p<0.01$ and ${ }^{\mathrm{b}} p<0.05$ vs controls 
activity. It is also suggested that inactivation of the thiol transport in diabetes is brought about at the early stage of cell life since decrease in the transport activity was similar in both the young and old erythrocytes, in comparison to those of normal control subjects.

In conclusion, GSH synthesis and thiol transport are impaired in erythrocytes from diabetic patients and K562 cells exposed to high glucose concentration. The decrease in $\gamma$-GCS activity is caused both by inactivation of the enzyme protein and a decrease in the expression of mRNA. The cells under high glucose conditions are sensitive to oxidative stress. The impaired cells circulate in the vessels and are exposed to endothelial cells and interactions involving endothelial cell function and impaired erythrocytes may occur. Although our results are probably applicable to other tissue cells, however, since we studied only erythrocytes, these weakened defence systems may contribute to explaining the pathogenesis of complications in diabetes.

Acknowledgements. This work was supported in part by grantsin-aids from the Ministry of Education, Science and Culture of Japan and Mitsui Life Social Welfare Foundation. The authors are grateful for the expert technical assistance of M. Ohta and J. Tagaya.

\section{References}

1. Wolf SP (1987) The potential role of oxidative stress in the diabetic complications: novel implications for theory and therapy. In: Crabbe MJC (ed) Diabetic complications, scientific and clinical aspects. Churchill Livingstone, Edinburgh, pp 167-220

2. Lyons TJ, Silvestri G, Dunn JA, Dyer DG, Baynes JW (1991) Role of glycation in modification of lens crystallins in diabetic and nondiabetic senile cataracts. Diabetes 40: 1010-1015

3. Meister A (1985) Methods for the selective modification of glutathione metabolism and study of glutathione transport. Methods Enzymol 113: 571-585

4. Richman P, Meister A (1975) Regulation of $\gamma$-glutamylcysteine synthetase by nonallosteric feedback inhibition by glutathione. J Biol Chem 250: 1422-1426

5. Yan N, Meister A (1990) Amino acid sequence of rat kidney $\gamma$-glutamylcysteine synthetase. J Biol Chem 265: 1588-1593

6. Goldwin AK, Meister A, O'Dwyer PJ, Haung CS, Hamilton TC, Anderson ME (1992) High resistance to cisplatin in human ovarial cancer cell lines is associated with marked increase of glutathione synthesis. Proc Natl Acad Sci USA 89: 1070-1074

7. Fujii S, Dale GL, Beutler E (1984) Glutathione-dependent protection against oxidative damage of the human red cell membrane. Blood 63: 1094-1101

8. Murakami K, Kondo T, Ohtsuka Y, Fujiwara Y, Shimada M, Kawakami Y (1989) Impairment of glutathione metabolism in erythrocytes from patients with diabetes mellitus. Metabolism 38: 753-758

9. Tagami S, Kondo T, Yoshida K, Hirokawa J, Ohtsuka Y, Kawakami Y (1992) Effect of insulin on impaired antioxi- dants in aortic endothelial cells from diabetes mellitus. Metabolism 41: 1053-1058

10. Pickett CB, Lu AYH (1989) Glutathione S-transferases: Gene structure, regulation, and biological function. Ann Rev Biochem 58: 743-764

11. Board PG (1981) Transport of glutathione S-conjugate from human erythrocytes. FEBS Lett 124: 163-165

12. Kondo T, Murao M, Taniguchi N (1982) Glutathione S-conjugate transport using inside-out vesicles from human erythrocytes. Eur J Biochem 125: 551-554

13. Awasthi YC, Misra G, Rassin DK, Srivastava SK (1983) Detoxification of xenobiotics by glutathione S-transferase in erythrocytes: the transport conjugate of glutathione and 1-chloro-2, 4-dinitrobenzene. Br J Haematol 55: 419-425

14. Ishikawa T, Sies H (1984) Cardiac transport of glutathione disulfide and S-conjugate. J Biol Chem 259: 3838-3843

15. Kobayashi K, Sogame Y, Hara H, Hayashi K (1990) Mechanism of glutathione S-conjugate transport in canalicular and basolateral rat liver plasma membrane. J Biol Chem 265: 7737-7741

16. Kondo T, Dale GL, Beutler E (1980) Glutathione transport by inside-out vesicles from human erythrocytes. Proc Natl Acad Sci USA 77; 6359-6362

17. LaBelle EF, Singh SV, Ahmad H, Wronski L, Srivastava SK, Awasthi YC (1988) A novel dinitrophenyl glutathione stimulated ATPase is present in human erythrocyte membranes. FEBS Lett 228: 53-56

18. Kondo T, Yoshida K, Urata Y, Goto S, Gasa S, Taniguchi N (1993) $\gamma$-Glutamylcysteine synthetase and active transport of glutathione $\mathrm{S}$ - conjugate transport are responsive to heat shock in K562 erythroid cells. J Biol Chem 268: 20366-20372

19. Kondo T, Sakai M, Isobe $H$ et al (1991) Induction of carbonic anhydrase I isozyme precedes the globin synthesis during erythropoiesis in K562 cells. Am J Hematol 38: 201-206

20. Beutler E, West C, Blume RV (1976) The removal of leukocytes and most platelets from whole blood. J Lab Clin Med 88: $328-333$

21. Kondo T, Ohtsuka Y, Shimada M et al. (1987) Erythrocyteoxidized glutathione transport in pyrimidine $5^{\prime}$ - nucleotidase deficiency. Am J Hematol 26:37-45

22. Lunn G, Dale GL, Beutler E (1979) Transport accounts for glutathione turnover in human erythrocytes. Blood 47 : 645-650

23. Vettore L, DeMatteis MC, Zampini P (1980) A new density gradient system for the separation of human red blood cells. Am J Hematol 8: 291-296

24. Kondo T (1989) Preparation of microcapsule from human erythrocytes: use in transport experiments of glutathione and its S-conjugate. Methods Enzymol 171: 217-225

25. Wahllander A, Sies H (1979) Glutathione S-conjugate formation from 1-chloro-2, dinitrobenzene and biliary S-conjugate excretion in the perfused rat liver. Eur $\mathrm{J}$ Biochem 98: 441-446

26. Beutler E, Gelbart T (1986) Improved assay of the enzymes of glutathione synthesis: $\gamma$-glutamylcysteine synthetase and glutathione synthetase. Clin Chim Acta 158: 115-123

27. Beutler E (1984) A manual of biochemical methods. In: Beutler E (ed) Red cell metabolism, 3rd edn. Grune and Stratton, Orlando, pp 77-136

28. Kaplow LS (1979) Leukocyte peroxidase and nonspecific erastase. In: Melamed MR, Mullaney PF, Mendelsohn ML (eds) Flow cytometry and sorting. John Willey \& Sons, New York, pp 531-545

29. Sambrook J, Fritsch EF, Maniatis T (1989) Molecular cloning. In: Sambrook J, Fritsch EF, Maniatis T (eds) A Labora- 
tory manual, 2nd. Cold Spring Harbor Laboratory Press, New York, pp 7-39

30. Amemiya Y, Miyahara J (1988) Imaging plate illuminates many fields. Nature 336: 89-90

31. Mosmann T (1983) Rapid colorimetric assay for cellular growth and survival: application to proliferation and cytotoxicity assays. J Immunol Methods 65: 55-63

32. Meister A (1983) Selective modification of glutathione metabolism. Science 220: 472-477

33. Martensson J, Steinherz R, Jain A, Meister A (1989) Glutathione ester prevents buthionine sulfoximine-induced cataracts and lens epithelial cell damage. Proc Natl Acad Sci USA 86: 8727-8731

34. Oogawara T, Kawamura N, Kitagawa Y, Taniguchi N (1992) Site- specific and random augmentation of $\mathrm{Cu}$, $\mathrm{Zn}$-superoxide dismutase by glycation reaction: implication of reaction oxygen species. J Biol Chem 267: 1850518510

35. Kondo T, Murakami K, Ohtsuka Y et al. (1987) Estimation and characterization of glycosylated carbonic anhydrase I in erythrocytes from patients with diabetes mellitus. Clin Chim Acta 166: 227-236
36. Mazzanti L, Faloia E, Rabin RA (1992) Diabetes mellitus induces red blood cell plasma membrane alterations possibly affecting the aging process. Clin Med 25: 41-46

37. Schwartz RS, Madsen JW, Rybicki RC, Negel RL (1991) Oxidation of spectrin and deformability defects in diabetic erythrocytes. Diabetes 40: 701-708

38. Hasegawa H, Shigeta Y, Egawa K, Kobayashi M (1991) Impaired autophosphorylation of insulin receptors from abdominal skeletal muscles in nonobese subjects with NIDDM. Diabetes 40: 815-819

39. Brownlee M, Vlassara H, Kooney A et al. (1986) Aminoguanidine prevents diabetes-induced arterial wall protein cross-linking. Nature 232: 1629-1632

40. Oxlund H, Andreassen TT (1992) Aminoguanidine treatment reduces the increase in collagen stability of rats with experimental diabetes mellitus. Diabetologia 35: 19-25

41. Mazzanti L, Faloia E, Rabin RA (1992) Diabetes mellitus induces red blood cell plasma membrane alterations possibly affecting the aging process. Clin Med 25: 41-46

42. Schwartz RS, Madsen JW, Rybicki RC, Negel RL (1991) Oxidation of spectrin and deformability defects in diabetic erythrocytes. Diabetes 40: 701-708 